7. Малеин Н.С. Возмещение вреда, приченённого личности. Москва : Юридическая литеpamypa, $1965.230 \mathrm{c}$.

8. Михно Е.А. Компенсация морального вреда во внедоговорных обязательствах : автореф. дис. ... к.ю.н. : 12.00 .03 - Гражданское право; Семейное право; Гражданский процесс; Международное частное право ; Санкт-Петербургский государственный университет. Санкт-Петербург, 1998. 35 с.

УДК 341.9

DOI https://doi.org/10.32844/2618-1258.2019.5-2.10

ЛУКАНЬ М.О.

\title{
КОНФЛІКТ ОСНОВНИХ ПРАВ ЛЮДИНИ 3 ПРАВОМ ІНТЕЛЕКТУАЛЬНОЇ ВЛАСНОСТІ: ЄВРОПЕЙСЬКИЙ ДОСВІД
}

Статтю присвячено дослідженню конфлікту фундаментальних прав людини, гарантованих Хартією основних прав Європейського Союзу та Європейською конвенцією про захист прав людини і основних свобод із правом на захист інтелектуальної власності. В статті розглянуті підходи суду Європейського Союзу до вирішення таких зіткнень. Наведено міркування про важливість вирішення зазначених конфліктів заради справедливого балансу приватних прав та інтересів кожної людини й економічного добробуту людства.

Приділено увагу випадкам протистояння права на захист особистих (персональних) даних, права на повагу до приватного та сімейного життя, права на банківську таємницю та права на повагу до інтелектуальної власності. Несправедливий баланс між правом на повагу та захистом інтелектуальної власності та правом на захист персональних даних призводить до зневаги інтелектуальних здобутків правовласників та ускладнює притягнення до відповідальності порушників.

Проаналізовано узгодження положень Хартії основних прав Європейського Союзу та Європейської конвенції про захист прав людини і основних свобод, Регламенту (СС) 2016/679 Європейського Парламенту та Ради від 27 квітня 2016 року про захист фізичних осіб у зв'язку з опрацюванням персональних даних, про вільний рух таких даних і про скасування Директиви 95/46/СС («Загальний регламент про захист даних» (General Data Protection Regulation - GDPR), Директиви 95/46/ ЄС від 24 жовтня 1995 року про захист окремих служб у відносинах з обробкою фізичних даних і про вільне переміщення цих даних, Директиви 2002/58/€С від 12 липня 2002 року про конфіденційність та електронні комунікації та основного документа, які стосується захисту прав інтелектуальної власності на європейському просторі, - Директиви № 2004/48/ЄС Європейського парламенту і Ради ЄС про забезпечення прав на інтелектуальну власність.

Сформовано висновки відповідно до підходів, які базуються на базових принципах ЄС та практиці суду Європейського Союзу, якими слід керуватися при виникненні конфліктів основних прав і права інтелектуальної власності з метою забезпечення справедливого балансу.

Ключові слова: захист інтелектуальної власності, основні права, захист персональних даних, суд Європейського Союзу, «Загальний регламент про захист даних».

The article is devoted to the study of the conflict of fundamental human rights guaranteed by the Charter of Fundamental Rights of the European Union and the European Convention for the Protection of Human Rights and Fundamental Freedoms with

(C) ЛУКАНЬ М.О. - аспірант кафедри міжнародного приватного права та порівняльного правознавства (Національний юридичний університет імені Ярослава Мудрого) 
the right to protection of intellectual property. In particular, the article examines the approaches of the Court of Justice of the European Union to resolving such conflicts. The article discusses the importance of resolving these conflicts for the sake of a fair balance of the private rights and interests of each person and the economic well-being of mankind.

Attention is paid to cases of confrontation between the right to protection of personal (personal) data, the right to respect for privacy and family life, the right to bank secrecy on the one hand, and the right to respect for intellectual property on the other. The unfair balance between the right to respect and protection of intellectual property and the right to protection of personal data leads to neglect of the intellectual property of the right holders and complicates the prosecution of violators.

The harmonization of the provisions of the Charter of Fundamental Rights of the European Union and the European Convention for the Protection of Human Rights and Fundamental Freedoms, Regulation (EU) 2016/679 of the European Parliament and of the Council of 27 April 2016 on the protection of individuals with regard to the processing of personal data the movement of such data and the repeal of Directive 95/46/EC (General Data Protection Regulation (GDPR), Directive 95/46/EC of 24 October 1995 on the protection of certain services in the processing of physical data and free movement of this data, Directive 2002/58/EC of 12 July 2002 on confidentiality and electronic communications and the main document concerning the protection of intellectual property rights in the European area - Directive 2004/48/EC of the European Parliament and of the Council on the protection of intellectual property rights intellectual property.

The conclusions are drawn in accordance with approaches based on the EU's basic principles and the case law of the Court of Justice of the European Union, which should be guided in the event of a conflict of fundamental rights and intellectual property rights in order to ensure a fair balance.

Key words: protection of intellectual property, fundamental rights, protection of personal data, Court of Justice of the European Union, "General Data Protection Regulation".

Вступ. Натепер значна популяризація надається питанню захисту персональних даних і притягнення винних осіб за незаконну обробку, збирання, розкриття персональних даних особи. Епоха кіберпростору дозволяє розповсюдити приватну інформацію про особу в лічені секунди, тим самим наразивши ії на небезпеку. В той самий час безмежні комунікаційні можливості інтернету дозволяють із легкістю розповсюджувати контрафактний товар і порушувати права інтелектуальної власності. У зв'язку з цим на практиці відбуваються конфлікти, пов'язані зі складнощами викриття порушників прав інтелектуальної власності та притягненням їх до відповідальності, що потребують розкриття конфіденційних персональних даних.

Постановка завдання. Метою статті є дослідження сутності, значення та підходів вирішення конфліктів основних прав людини з правом інтелектуальної власності.

Результати дослідження. Дослідженням цієї теми займаються такі вчені як Мартін Хусовець [6], Йозеф Дрексл [8], Пекка Савола [7] та інші.

У травні 2018 року вступив у дію Регламент (СС) 2016/679 Європейського Парламенту та Ради від 27 квітня 2016 року про захист фізичних осіб у зв'язку з опрацюванням персональних даних і про вільний рух таких даних, про скасування Директиви 95/46/ЄС «Загальний регламент про захист даних» (General Data Protection Regulation - GDPR) [2]. Захист, передбачений цим регламентом, поширюється на фізичних осіб незалежно від їхнього громадянства чи місця проживання під час опрацювання їхніх персональних даних. Регламент розкриває зміст «персональних даних», до яких належить будь-яка інформація, яка стосується фізичної особи, яку ідентифіковано чи можна ідентифікувати за такими ідентифікаторами як ім'я, ідентифікаційний номер, дані про місцеперебування, онлайн-ідентифікатор або за одним чи декількома факторами, що є визначальними для фізичної, фізіологічної, генетичної, розумової, економічної, культурної чи соціальної сутності такої фізичної особи.

У зв'язку з таким загостреним ставленням до захисту персональних даних однією з найбільших проблем, яка постає перед правовласниками об'єктів інтелектуальної власності, це ідентифікація порушника особливо в інтернеті. Правовласникам об'єктів інтелектуальної власності часто доводиться звертатися до третіх сторін таких як постачальники послуг інтернету або реє- 
страторів доменних імен, щоб ідентифікувати особу порушника (електронну пошту порушника, його IP-адресу, ім'я), а це нібито порушує право особи на конфіденційність. У результаті пошуки порушника перетворюються на дуже повільний і затратний процес для правовласника і створює сприятливий клімат для контрафактної продукції.

Положення Директиви ЄС № 2004/48 про захист прав інтелектуальної власності [4] вимагають, щоб європейські держави-члени гарантували, що національні суди можуть наказати порушникам або третім сторонам, які беруть участь у виробництві чи продажі контрафактної продукції, розкривати інформацію про порушника. Автор розглядає такі сучасні ситуації, в яких суд ЄС сформував підходи вирішення зазначених конфліктів.

\section{1. «Право інтелектуальної власності vs захист особистих даних».}

Це протиборство стосується забезпечення справедливого балансу між захистом прав інтелектуальної власності, якими користуються правовласники, і захистом особистих даних, якими користуються інтернет-абоненти або користувачі.

Захист фізичних осіб, який стосується обробки персональних даних, є фундаментальним правом людини. Це проголошує стаття 8 (1) Хартії основних прав Європейського Союзу [1]. Також відповідно до статті 8 Європейської конвенції про захист прав людини і основних свобод (СКПЛ) кожен має право на повагу до свого приватного життя і до таємниці кореспонденції.

Так, за обставинами справи "Bonnier Audio AB, Earbooks AB, Norstedts Förlagsgrupp AB, Piratförlaget AB, Storyside AB v. Perfect Communication Sweden AB" (Case C-461/10) [10] шведські видавничі компанії, які володіють ексклюзивними правами на відтворення, публікацію та розповсюдження серед громадськості 27 творів у формі аудіо-книг, стикнулися з тим, що їх ексклюзивні права були порушені публічним розповсюдженням цих 27 творів без їхньої згоди через сервер FTP (“file transfer protocol” - «протокол передачі файлів»), який дозволяє обмінюватися файлами та передавати дані між комп’ютерами, підключеними до інтернету.

Інтернет-провайдер, через який відбувся незаконний обмін файлами, це еPhone. Тож заявники звернулися до національного суду Швеції з заявою про розголошення приватних даних, а саме імені та адреси особи, що використовує IP-адресу, з якої відбувся незаконний обмін файлами. Зі свого боку інтернет-провайдер еPhone оскаржив цю заяву, аргументуючи це тим, що розкриття такої інформації буде порушенням права на приватну інформацію, що суперечить Директиві 2006/24 [3]. Директива 2002/58/ЄС від 12 липня 2002 року про конфіденційність та електронні комунікації підтримує обробку персональних даних і захищає конфіденційність у секторі електронних комунікацій.

Суд СС, розглядаючи цю справу, вирішив, що стаття 8 Директиви № 2004/48/СС Свропейського парламенту і Ради ЄС про забезпечення прав на інтелектуальну власність регламентує, що держави-члени забезпечують, щоб у разі розгляду справи про порушення права інтелектуальної власності та у відповідь на виправданий і пропорційний запит заявника компетентні судові органи могли розпорядитися інформацією про походження та мережі розповсюдження товарів чи послуги, які порушують право інтелектуальної власності, від порушника та/або будь-яких інших осіб, які підпадають під вимоги, встановлені цією статтею.

Стосовно витребування інформації, про яку йдеться у Директиві 2004/48, то таке витребування переслідує мету отримання порушником (відповідачем) заяви про порушення прав інтелектуальної власності. Таким чином $є$ виправданим розкриття персональних даних про особу для забезпечення справедливого балансу між захистом прав інтелектуальної власності, якими користуються правовласники, і захистом особистих даних, якими користуються інтернет-абоненти або користувачі.

При цьому національне законодавство держав-членів повинно встановлювати можливість національному суду, який розглядає заяву про розголошення персональних даних, зважувати суперечливі інтереси сторін, які беруть участь у справі, на підставі фактів кожної конкретної справи 3 належним врахуванням вимог принципу пропорційності; національне законодавство повинно вимагати чітких доказів порушення права інтелектуальної власності, які переконливо засвідчують, що розкриття інформації може розглядатися як сприяння розслідуванню порушення прав інтелектуальної власності, і що наслідки від порушення права IB переважають наслідки розкриття приватної інформації або для іншого конфліктного інтересу. життя».

2. «Право інтелектуальної власності vs право на повагу до приватного та сімейного

В рамках справи "Bastei Lübbe GmbH \& Co. KG v Michael Strotzer" 2018 року [9] суд $6 C$ розглядав позов німецького видавця Bastei Lübbe GmbH \& Co. KG до Майкла Штротцера про відшкодування збитків у результаті порушення авторських прав за допомогою обміну файлами 
через інтернет. Однак у суді відповідач заперечив, що порушив авторські права, оскільки стверджував, що його батьки, які живуть у тому ж домогосподарстві, що й він, також мали доступ до інтернету.

Згідно з практикою Федерального суду Німеччини (Bundesgerichtshof), якщо інтернет-з'єднання було недостатньо захищене або свідомо було доступне для інших осіб - членів сім'ї, то власник цього з'єднання вважається таким, що не вчиняв порушення. При цьому власник інтернет-зв'язку не зобов'язаний надавати додаткові деталі, які стосуються часу та характеру використання цього з'єднання, з огляду на повагу приватного життя та сім'ї, гарантованого статтею 7 Хартії основних прав Європейського Союзу.

Вирішуючи цю справу, суд ЄС зазначив, що основною метою Директиви 2001/29 про узгодження певних аспектів авторського права та суміжних прав в інформаційному суспільстві [5] $\epsilon$ встановлення високого рівня захисту авторських і суміжних прав, оскільки такі права мають вирішальне значення для інтелектуальної творчості. Для досягнення цієї мети в статті 8 (1) Директиви 2001/29 йдеться, що держави-члени повинні передбачити відповідні санкції та засоби правового захисту щодо порушень у сфері інтелектуальної власності, які повинні бути ефективними, пропорційними та стримуючими. Мета, яку переслідує Директива 2004/48, полягає в тому, щоб привести у відповідність системи законодавства держав-членів щодо засобів захисту прав інтелектуальної власності, забезпечити високий, еквівалентний і однорідний рівень захисту на внутрішньому ринку.

Повага до основного права на захист сімейного життя в цьому випадку перешкоджає потерпілій стороні отримувати докази, необхідні для підтвердження своїх вимог. Директиви 2004/48 «поважає» основні права та дотримується принципів, визнаних, зокрема, Хартією. Так, ця директива спрямована на забезпечення повної поваги до інтелектуальної власності відповідно до статті 17 (2) Хартії. У протилежному ж випадку, коли $\epsilon$ перешкоди для правовласників в ідентифікації порушника, вони тільки сприятимуть порушенню авторських прав та уникненню відповідальності за ці порушення. Основні права на ефективний засіб захисту прав та інтелектуальної власності, яким користується власник авторських прав, серйозно порушуються, i тим самим не дотримується вимога забезпечити справедливий баланс між різними основними правами.

\section{3. «Право інтелектуальної власності vs банківська таємниця»}

За обставинами справи "Coty Germany GmbH v Stadtsparkasse Magdeburg” [11] Coty Germany виробляє і поширює парфумерію і має ексклюзивну ліцензію на парфумерію під торговою маркою Community Davidoff Hot Water. Coty Germany придбала флакон парфумів із торговою маркою Davidoff Hot Water на інтернет-аукціоні, сплативши кошти на банківський рахунок, відкритий на цьому інтернет-аукціоні Stadtsparkasse. Виявивши, що це контрафактний продукт, Coty Germany попросила цю аукціонну платформу надати ім'я власника рахунку. Stadtsparkasse, посилаючись на банківську таємницю, відмовився надати Coty Germany цю інформацію.

Вирішуючи цю справу, суд ЄС зазначив, що, спираючись на статтю 8 (3) (е) Директиви 2004/48/СС про захист прав інтелектуальної власності, банківська установа не має права посилатися на «необмежену і беззастережну силу банківської таємниці», для того, щоб відмовити надати інформацію про порушника, яка стосується імені та адреси рахунку-держателя.

Висновки. За такої широкої практики, пов'язаної з цинічним порушенням прав інтелектуальної власності і ускладненими процедурами притягнення порушників до відповідальності, можна говорити про відсутність загального світового чи європейського узгодженого підходу до інтелектуальної власності як цінності, захищеної статтею 17 (2) Хартії основних прав ЄС.

Національне законодавство держав-членів повинно встановлювати можливості для спрощення процедури розкриття персональних даних, зважаючи на факти кожного випадку з належним врахуванням вимог принципу пропорційності. Національне законодавство повинно вимагати чітких доказів порушення права інтелектуальної власності, які переконливо засвідчують, що розкриття конфіденційної інформації сприяє розслідуванню порушення прав інтелектуальної власності, і що наслідки від порушення права інтелектуальної власності переважають наслідки розкриття приватної інформації або іншого конфліктного інтересу.

На думку автора, складається таке враження, що всі заходи спрямовані на ускладнення правовласнику захистити своє право інтелектуальної власності. Оскільки потерпілій стороні, крім складнощів доведення факту такого порушення і доведення збитків, ще й треба боротися за право на ідентифікацію порушника. Хоча за логікою потерпілій стороні мають надаватися все ж більш обнадійливі інструменти захисту. 


\section{Список використаних джерел:}

1. Charter of Fundamental Rights of the European Union of 7 December 2000. URL: https:/eur-lex.europa.eu/legal-content/EN/TXT/?uri=CELEX:12012P/TXT (дата звернення: 26.01.2020).

2. Regulation (EU) 2016/679 of the European Parliament and of the Council of 27 April 2016 on the protection of natural persons with regard to the processing of personal data and on the free movement of such data, and repealing Directive 95/46/EC (General Data Protection Regulation). URL: https://eur-lex.europa.eu/eli/reg/2016/679/oj (дата звернення: 27.01.2020).

3. Directive 2006/24/EC of the European Parliament and of the Council of 15 March 2006 on the retention of data generated or processed in connection with the provision of publicly available electronic communications services or of public communications networks and amending Directive 2002/58/EC. URL: https://eur-lex.europa.eu/legal-content/GA/TXT/?uri=CELEX:32006L0024 (дата звернення: 25.01.2020).

4. Directive 2004/48/EC of the European Parliament and of the Council of 29 April 2004 on the enforcement of intellectual property rights (OJ L 157, 30.4.2004). URL: https://eur-lex.europa.eu/legalcontent/EN/TXT/?uri=CELEX\%3A32004L0048R\%2801\%29 (дата звернення: 25.01.2020).

5. Directive 2001/29/EC of the European Parliament and of the Council of 22 May 2001 on the harmonisation of certain aspects of copyright and related rights in the information society. URL: https://eur-lex.europa.eu/legal-content/EN/TXT/?uri=celex\%3A32001L0029 (дата звернення: 27.01.2020).

6. Martin Husovec. Intellectual Property Rights and Integration by Conflict: The Past, Present and Future. Cambridge Yearbook of European Legal Studies, 18 (2016), P. 239-269.

7. Pekka Savola. Proportionality of Website Blocking: Internet Connectivity Providers as Copyright Enforcers. https://papers.ssrn.com/sol3/papers.cfm?abstract_id=2432259. URL: (дата звернення: 02.02.2020).

8. Josef Drexl. European and International Intellectual Property Law between Propertization and Regulation: How a Fundamental-Rights Approach Can Mitigate the Tension. URL: https://www.mcgeorge.edu/documents/Publications/drexlTUOPLR472.pdf(дата звернення: 02.02.2020).

9. Bastei Lübbe GmbH \& Co. KG v Michael Strotzer. Case C-149/17. Judgment of the court (Third Chamber) of 18 October 2018. URL: http://curia.europa.eu/juris/document/document.jsf? text $=\&$ docid $=206891$ \&pageIndex $=0 \&$ doclang $=$ en\&mode $=1$ st \&dir $=\& o c c=$ first\&part $=1 \& \operatorname{cid}=2678182$ (дата звернення: 26.01.2020).

10. Bonnier Audio AB, Earbooks AB, Norstedts Förlagsgrupp AB, Piratförlaget AB, Storyside AB v Perfect Communication Sweden AB. Case C-461/10 Judgment of the court (Third Chamber) of 19 April 2012. URL: http://curia.europa.eu/juris/document/document.jsf?text=\&docid= 121743\&pageIndex $=0 \&$ doclang $=$ en $\&$ mode $=1$ st\&dir $=\& o c c=$ first\&part $=1 \& c i \quad$ (дата 25.01.2020).

11. Coty Germany GmbH v Stadtsparkasse Magdeburg. Judgment of the court (Fourth Chamber) of 16 July 2015. Case C-580/13. URL: http://curia.europa.eu/juris/document/document.jsf?text=\&doci $\mathrm{d}=165900$ \&pageIndex=0\&doclang=en\&mode=lst\&dir=\&occ=first\&part=1\&cid=3014419 (дата звернення: 27.01.2020). 